\title{
Hashtag Berkonten Seksual sebagai Gaya Komunikasi 'Kelompok Marginal' dan Bagaimana Tenaga Kesehatan Menjalankan Tugas?
}

\author{
Oleh Ainul Rafiq
}

Peneliti independen (non akademik), berafiliasi dengan STIKes Madani Yogyakarta melalui pekerjaan sebagai Tenaga Kependidikan. Dapat dihubungi melalui email ainulrafiq@stikesmadani.ac.id

Penyedia jasa yang layanannya begitu beragam sehingga hampir meliputi seluruh lini kehidupan manusia tersedia di internet. Sebut saja akses perbankan, beli perhiasan dan saham, melengkapi kebutuhan hidup bulanan, sampai pesan makanan sehari-hari. Dan yang tidak pernah ketinggalan adalah pemuasan kebutuhan seksual.

Kebutuhan seksual merupakan bawaan lahir yang diberikan oleh Pencipta sebagai fitrah manusia. Pengetahuan tentang seksual tercatat dalam sejarah umat manusia, dan melalui catatan tersebut kita saat ini mengetahui bahwa pemuasan kebutuhan seksual dapat melalui sesama jenis kelamin (homoseksual) dan lain jenis kelamin (heteroseksual). Dalam perkembangan manusia, eksistensi dua jenis pemuasan kebutuhan seksual ini selalu meninggalkan kesan masing-masing.
Oleh karena itu, kita menjadi mengerti bagaimana mereka berkomunikasi dan mendapatkan akses untuk memuaskan kebutuhan seksualnya.

Peran utama internet untuk memberikan hal yang dibutuhkan atau menjadi perantara tercapainya kebutuhan saat keinginan penyaluran seksual sedang tinggi-tingginya bukan rahasia lagi. Penggunaan internet untuk kebutuhan ini dapat dikatakan telah 'umum' bagi kalangan homoseksual, sebut saja penggunaan aplikasi berbasis internet untuk menemukan pasangan seks (Elford, Bolding dan Sherr, 2001; Macapagal, dkk., 2018).

\section{Mencari data}

Data dihimpun menggunakan Drone Emprit Academic (DEA) mulai dari tanggal 1 Agustus 2019 hingga 27 September 2019. 
Agar dapat menggunakan DEA sebelumnya wajib mendaftar melalui laman https://dea.uii.ac.id. Topik-topik yang disediakan oleh DEA berdasar kepada Sustainable Development Goals (SDGs) yang berjumlah 17 tema utama (dea.uii.ac.id).

\section{Hashtag populer}

Setelah dianalisis kelompok hashtag

tersebut mengandung hal berikut:

1. Konten pornografi berisi gambar dan/atau video yang memperlihatkan organ kelamin dan adegan hubungan seksual yang diperoleh melalui hasil prank, retweet dari akun pembuat video pornografi dan/atau pribadi dan atau mention ke akun yang bertugas seperti perpustakaan konten pornografi.

2. Konten yang menampilkan gambar untuk mempromosikan jasa pijat, mencari pasangan dan ajakan untuk menginstall aplikasi eksternal.

\section{Kemungkinan yang bisa terjadi}

Penggunaan hashtag untuk berkomunikasi adalah sebagai media yang memudahkan tersampaikannya pesan (Laucuka, 2018), kemudian jika penerima pesan menanggapi konten yang dibawa oleh pesan tersebut maka hal yang dapat terjadi adalah:

1. Penggunaan konten pornografi yang dibawa oleh hashtag digunakan sebagai perantara pemuasan kebutuhan seksual, konten tersebut membangkitkan rangsangan seksual.

2. Mencari dan menemukan pasangan dengan jalan 'jasa pijat' atau secara langsung mengutarakannya. Pasangan yang didapatkan dapat berasal dari sesama daerah atau luar daerah dan kemudian saling janji menentukan waktu bertemu.

3. Promosi agar menginstall aplikasi eksternal. Hal ini terlihat dari hashtag Bluedld, yang berisi konten pornografi disertai ajakan untuk mengunduh dan menggunakan aplikasi tersebut. Aplikasi Bluedld berisi konten adegan hubungan seks, menampilkan organ kelamin dan bentuk tubuh. Kendatipun aplikasi ini telah dilarang penggunaannya oleh

Pemerintah 


(www.kominfo.go.id), namun
masyarakat masih dapat
mengunduhnya secara bebas
melalui perpustakaan awan.

\section{Peran penting tenaga kesehatan}

Pemanfaatan sosial media sebagai wadah menyampaikan pesan-pesan kesehatan perlu dilakukan oleh tenaga kesehatan, cara baru ini dapat diisi dengan bercerita, mengirim konten yang membuat orang lebih perhatian pada kesehatannya, promosi kesehatan, dan bahkan bantuan oleh komunitas (peer support) (Charalambous, 2019). Lebih khusus kepada media sosial Twitter yang penggunaannya selain dapat menyimpan gambar dan tulisan, media sosial ini masih disukai oleh kelompok marginal (baca: komunitas homoseksual).

Menggunakan hashtag untuk
menyebarkan konten-konten yang
mengandung unsur pornografi melalui
media sosial Twitter dapat dimanfaatkan
datanya oleh tenaga kesehatan yang
berperan dalam promosi kesehatan
kepada kelompok marginal. Tenaga
kesehatan membuat konten yang
mengandung pesan sesuai tema yang ingin
dibahas dengan menggunakan kalimat
yang jelas (tidak ambigu) dan lebih baik lagi

disertakan gambar sebagai bahan inspirasi pembaca (Edney dkk., 2018).

\section{Kesimpulan}

Melalui kajian ini dapat disimpulkan bahwa dengan adanya dan begitu mudahnya penggunaan internet dewasa ini telah menggantikan cara berkomunikasi tatap muka kelompok homoseksual. Salah satu media yang mereka gunakan untuk berkomunikasi adalah media sosial Twitter yang untuk dapat menikmati konten yang ada, cukup dengan membuka media sosial tersebut baik melalui smartphone atau website.

Perilaku Lelaki Seks dengan Lelaki sangat mungkin terjadi setelah mengakses konten yang ada di media sosial Twitter yang bisa diakses oleh anak kecil hingga dewasa. Oleh karena itu, penulis menyarankan kepada aktivis, tenaga kesehatan, dan peneliti yang ingin memberikan pendidikan kesehatan dengan target kelompok marginal ini untuk menggunakan hashtag yang populer dikalangan mereka.

\section{Ucapan terimakan}

Ucapan terimakasih kepada Drone Emprit Academic yang layanannya disediakan oleh Universitas Islam Indonesia. 


\section{Daftar pustaka}

Charalambous, A. (2019). Social Media and Health Policy. Asia-Pacific Journal of Oncology Nursing, 6(1), p.24.

Edney, S., Bogomolova, S., Ryan, J., Olds, T., Sanders, I. dan Maher, C. (2018). Creating Engaging Health Promotion Campaigns on Social Media: Observations and Lessons From Fitbit and Garmin. Journal of Medical Internet Research, 20(12), p.e10911

Elford, J., Bolding, G. dan Sherr, L. (2001). Seeking sex on the internet and sexual risk behaviour among gay men using London gyms. AIDS, 15(11), pp.1409-1415.

https://dea.uii.ac.id/

https://kominfo.go.id/content/detail/124

49/kominfo-minta-google-cabut-73aplikasi-lgbt-dari-playstore/0/sorotan_media

Laucuka, A. (2018). Communicative Functions of Hashtags. Economics and Culture, 15(1), pp.56-62.

Macapagal, K., Moskowitz, D., Li, D., Carrión, A., Bettin, E., Fisher, C. dan Mustanski, B. (2018). Hookup App Use, Sexual Behavior, and Sexual Health Among Adolescent Men Who Have Sex With men in the United States. Journal of Adolescent Health, 62(6), pp.708-715. 